\title{
Prevalence of Neisseria meningitidis carriers in children under five years of age and teenagers in certain populations of Mexico City
}

\author{
Luz Elena Espinosa de los Monteros, DSc, ${ }^{(1)}$ Felipe Aguilar-Ituarte, DCh, ${ }^{(2)}$ Leticia Verónica Jiménez-Rojas, MSc, ${ }^{(2)}$ \\ Pablo Kuri, MSc, ${ }^{(3)}$ Romeo S Rodríguez-Suárez, DCh, ${ }^{(4)}$ Demóstenes Gómez-Barreto, DCh. ${ }^{(1)}$
}

Espinosa de los Monteros LE, Aguilar-Ituarte F, Jiménez-Rojas LV, Kuri P, Rodríguez-Suárez RS, Gómez-Barreto D.

Prevalence of Neisseria meningitidis carriers in children under five years of age and teenagers in certain populations of Mexico City. Salud Publica Mex 2009;5 I: I 14-I 8.

\begin{abstract}
Objective. To carry out a pilot study to discover the frequency of colonization in healthy children under five years old and teenagers, as well as the distribution of the different $N$. meningitidis serogroups isolated from nasopharyngeal samples collected from the population under study. Material and Methods. The population included youth between I5 and 19 years old living in social rehabilitation centers (SRC) and university teenagers (UT) as well as children under the age of five attending day care centers (DCC) in Mexico City. Nasopharyngeal exudates were processed using standard microbiological techniques in order to identify $\mathrm{Nm}$, the serogroup, type and subtype of these isolates. Results. A total of 2310 samples (774 SRC, 800 UT and 736 DCC) were taken. Total prevalence of $\mathrm{Nm}$ was $\mathrm{I} .6$ per cent. In teenagers living in SRC the prevalence was $2.9 \%$. The most frequent serogroups were Y (29.7\%), C (24.3\%) and B (10.8\%). Conclusions. The prevalence of carriers in the study environment was significant (I.6\%) and similar to countries in which the invasive illness is much more frequent.
\end{abstract}

Key words: Neisseria meningitidis, serogroup; nasopharynx
Espinosa de los Monteros LE,Aguilar-Ituarte F, Jiménez-Rojas LV, Kuri P, Rodríguez-Suárez RS, Gómez-Barreto D.

Prevalencia de portadores de Neisseria meningitidis en niños menores de cinco años de edad y adolescentes en determinadas poblaciones de la Ciudad de México. Salud Publica Mex 2009;51: I I4-I I8.

\section{Resumen}

Objetivo. Realizar un estudio piloto que permita conocer la frecuencia de colonización en niños sanos menores de cinco años y adolescentes, así como la distribución de serogrupos de los aislamientos de Neisseria meningitidis ( $\mathrm{Nm}$ ) obtenidos de la nasofaringe de la población estudiada. Material y métodos. Se incluyeron, jóvenes entre los 15 y 19 años de edad, de centros de readaptación social (CRS) y adolescentes universitarios (AU), así como niños menores de cinco años que asisten a estancias infantiles (EI) en la Ciudad de México. Se tomaron exudados nasofaríngeos y fueron procesados, usando las técnicas microbiológicas clásicas, para identificar $\mathrm{Nm}$, serogrupo, tipo y subtipo de estos aislamientos. Resultados. Se incluyeron un total de 2310 muestras (774 CRS, $800 \mathrm{AU}$ y $736 \mathrm{El})$. La prevalencia total de $\mathrm{Nm}$ fue I.6\% y en los adolescentes de CRS fue 2.9 por ciento. Los serogrupos más frecuentes son; Y (29.7\%), C (24.3\%) y B (I0.8\%). Conclusión. La prevalencia de portadores en nuestro medio fue significativa (1.6\%) y similar a los países en los que la enfermedad invasiva es mucho más frecuente.

Palabras claves: Neisseria meningitidis serogrupo; nasofaringe

(I) Hospital General Dr. Manuel Gea González, México

(2) Hospital Infantil de México Federico Gómez, México

(3) Dirección General de Epidemiología, Secretaría de Salud, México

(4) Coordinador de Asesores, Secretaría de Salud, México

Received on: January 9, 2008 • Accepted on: November II, 2008

Address reprint requests to: Luz Elena Espinosa de los Monteros Pérez. Hospital General Dr. Manuel Gea González, Departamento de investigación en microbiología. Calzada de Tlalpan 4800, col. Sección XVI. I 4080 Delegación Tlalpan, México DF. E-mail: espinosaluzelena@hotmail.com 
$N$ eisseria meningitidis is a pathogen that lives exclusively in the oropharynx of human beings; it continues to be the most frequent cause of sepsis and meningitis in children around the world. ${ }^{1}$ Neisseria meningitidis can be found in the human being in the form of an asymptomatic carrier and in other instances causing serious invasive disease with high morbidity and mortality. Consequently, meningococcal disease has been considered an important public health problem; thus, the immediate reporting of its occurrence to health authorities is mandatory. Meningococcal disease can be present as isolated cases or outbreaks. When this happens it can cause epidemiological alarm among health authorities because of the risk that a small outbreak has of becoming an epidemic problem requiring immediate epidemiological measures (prophylaxis and vaccination) to control its outspread. ${ }^{2}$

The percentage of colonization varies depending on the age group: $2 \%$ in the pediatric age group such as infants and pre-school children and 10-39\% in teenagers and young adults. ${ }^{3,4}$ It must be pointed out that the increased prevalence of the carrier state may vary due to different factors related to living conditions and habits, immunological status, prior viral or bacterial disease, seasonal period, etc. Endemic and epidemic meningococcal infection occurs worldwide. It has been calculated that 500000 cases of invasive disease occur annually worldwide with more than 50000 deaths. ${ }^{5}$ In developed countries, death due to invasive disease is 8 to $13 \%$; the total number of cases may vary depending on the prevalence and nature of the disease, the social and immunological conditions of the patients and the socioeconomic level of each country. ${ }^{6-8}$ Between $9 \%$ and $11 \%$ of the patients who survive the disease are left with sequels (deafness, mental retardation, seizures, and limb amputations)..$^{7-8}$ The disease has seasonal variations, with the greatest incidence being observed during the winter and early spring months. ${ }^{6-10} \mathrm{In}$ addition, there is an association between influenza and invasive meningococcal disease. ${ }^{11}$

Traditionally, Neisseria meningitidis has been characterized by antibodies that recognize epitopes on the capsule or outer membrane. With the use of this technique, 13 serogroups (identifying capsular antigens) and 20 serotypes (identifying porine classes 2 or 3 ) have been identified. The subtypes are based on the antigenic differences in the outer membrane Protein 1 . The antigen responsible for the specificity of the serogroups is the capsular polysaccharide (A, B, C, D, X, Y, Z, 29E, W135, $\mathrm{H}, \mathrm{I}, \mathrm{J}$ and L). ${ }^{12}$

The $B$ and $C$ serogroup strains cause most of the infections in industrialized cities. The A serogroup and other strains are less extensive; the $C$ serogroup is the most significant in developing countries. ${ }^{13-16}$

Some studies have shown that many invasive meningococcal diseases are restricted to a specific number of hyper-virulent strains that contrast with carrier isolates that have never been associated with the disease; such is the case of the ET37 complex, characterized by a 2aP1.5P1.2 phenotype. ${ }^{17}$ This indicates that some meningococci are genetically adapted to cause invasive disease.

In Mexico, meningococcal disease has a very low incidence. However, the health department has recently reported an increasing number of cases; nonetheless, Mexico is still one of the countries with fewer cases of this disease (average of 55 cases in the last 6 years), ${ }^{21}$ though the prevalence of the carrier state is unknown.

The identification and detection of serotypes considered highly virulent will enable us to estimate the magnitude of the problem in our country; the origin of a potential epidemic outbreak could be foreseen and this would make it possible to set up the appropriate treatment measures and apply specific vaccines based on the serogroups identified in our population.

Thus, the purpose of this study is to carry out a pilot study to discover the frequency of colonization in healthy children under five years of age and teenagers, as well as the distribution of the different serogroups of $N$. meningitidis isolated from the nasopharyngeal exudates of the population under study.

\section{Material and Methods}

This is a descriptive, cross-sectional study with a nonprobabilistic group sampling from the healthy population, which includes youth between 15 and 19 years old living in social rehabilitation centers in Mexico, students attending several mexican universities and children under the age of five attending day care centers in Mexico City.

The study period was from September 2004 to April 2005. Informed consent was obtained from all participants and from the parents of children five years old and under. A local research and ethics committee approved the study.

The study excluded individuals with a diagnosis of primary or secondary immunodeficiency, hematological and/or oncological disease, acute respiratory disease, use of steroids or immunosuppressant drugs and craniofacial malformations.

Sample collection: The samples were collected by introducing a calcium alginate swab ${ }^{\mathrm{MR}}$ (Pur-Wraps) into the 
nasopharynx; the swabs were deposited directly into an Aimes transport medium and sent to the streptococcal laboratory at Hospital Infantil de México.

Laboratory Methods: The swabs were inoculated on 5\% sheep blood agar and Tayer Martin agar (Dickinson Microbiology Systems, Maryland, MD), and incubated at $37^{\circ} \mathrm{C}$ for 24 hours with a $5 \% \mathrm{CO}_{2}$ atmosphere; the colonies with typical Neisseria morphology were selected in accordance with the basic colony and microscopic morphology characteristics, as well as the differential tests necessary to arrive at the identification of Neisseria meningitidis. ${ }^{22,23}$ Using the group-specific antiserum agglutination technique (DIFCO), ${ }^{23}$ the serogroup of each of the isolates was identified.

The Neisseria meningitidis ATCC 35562 strain was included as assay quality control.

In order to find out the prevalence of serotypes, the isolates were sent to the microbiology laboratory at Manchester (Medical Microbiology Partnership, Manchester University, United Kingdom) in a whole-cell dot-blotting assay. ${ }^{24}$

\section{Results}

A total of 2310 participants were included in the study, of whom 736 were from day care centers (DCC), 800 were university teenagers (UT), and 774 were teenagers from social rehabilitation centers (SRC) (Table I).

\section{Microbiology}

Neisseria meningitidis was isolated from 37 out of 2310 $(1.6 \%)$ participants. N.meningitidis was isolated from 14 out of $736(1.9 \%)$ DCC children and 23 out of 774 $(2.9 \%)$ SRC youth. There were no isolations from the UT students (Table I).

\section{Serogroup distribution}

Serogroup distribution is shown in Table II. The most frequent serogroups were $Y(29.7 \%)$ and C $(24.3 \%)$.

\section{Serotype distribution}

Due to technical handling problems, only 23 of the 37 isolates were recovered, of which the predominant serotype was 2a.P1.5.12 (Table II).

\section{Discussion}

The prevalence of the carrier state is conditioned by inherent factors in the bacterium, the host, the envi-
Table I

Characteristics of the population included

IN THE PREVALENCE OF CARRIERS OF NEISSERIA MENINGITIDIS IN CHILDREN UNDER 5 YEARS OF AGE AND TEENAGERS From MEXICO CITY. 2004-2005

\begin{tabular}{lll}
\multicolumn{1}{c}{ Population } & \multicolumn{1}{c}{ Age range } & \multicolumn{1}{c}{$\begin{array}{c}\text { Frecuency of } \\
\text { N. meningitidis }\end{array}$} \\
Day care centers $\mathrm{n}=736$ & $2-71$ months & 14 isolates \\
\hline University students $\mathrm{n}=800$ & $15-19$ years & 0 \\
\hline Social rehabilitation centers $\mathrm{n}=774$ & $15-19$ years & 23 isolates
\end{tabular}

ronment, the sample-taking technique, the number of samples taken, and the sensitivity of the methodology that is used in the laboratory. ${ }^{23}$ Other factors that impact the carrier state are age, gender, socioeconomic level, exposure to tobacco, pollution, alcohol consumption in entertainment centers, immunological status, and viral and/or bacterial infections. ${ }^{3,4}$ In this study, the prevalence of N.meningitidis was $1.6 \%$. The group with the highest prevalence was the SRC teenagers and DCC children.

As reported in the literature, the nasopharyngeal carrier state is higher among populations with low socioeconomic level, living in overcrowded conditions, people who live in centers like prisons, military barracks, student dormitories, and people participating in pilgrimages. There are substantial variations in the age of individuals who are carriers of N.meningitidis. The higher rates are found in teenagers at the SRC $(2.97 \%)$ and the smaller percentages in infants and preschool children $(1.90 \%))^{3,4}$

In our study, we did not find a single nasopharyngeal carrier in the university population, despite the fact that they are among the age group ( 15 to 19 years old) with the highest prevalence of colonization; it is also the age in which more cases of fatal invasive disease are reported. ${ }^{3,4,25}$ The low prevalence in this group could be explained because only one nasopharyngeal sample was taken and/or because the population studied was immune with specific antibodies to the most prevalent types of N.meningitidis seen in the carrier state., ${ }^{9,26}$

We know that $N$ meningitidis is transmitted by direct person-to-person contact via micro drops of pflugge that contain the meningococcus, ${ }^{17}$ and that this increases in closed populations in contrast to open populations where transmission is low. It must also be considered that there are chronic carriers $(30 \%)$, intermittent ones $(30 \%)$, and transitory carriers (40\%); this fact being a factor in the failure to isolate $\mathrm{N}$ meningitidis in a community 
Table II

Characteristics of the population included IN THE PREVALENCE OF CARRIERS OF NEISSERIA MENINGITIDIS IN CHILDREN UNDER FIVE YEARS OF AGE AND TEENAGERS in Mexico City and characteristics of isolates. 2004-2005

\begin{tabular}{|c|c|c|c|c|}
\hline Age & Sex & Group & Type & Subtype \\
\hline $16 \mathrm{~m}$ & M & NT & 4 & NT/NT/NT \\
\hline $10 \mathrm{~m}$ & $\mathrm{~F}$ & $\mathrm{C}$ & $2 a$ & $\mathrm{PI} .5 / \mathrm{PI} .2 / \mathrm{NT}$ \\
\hline $6 \mathrm{~m}$ & $M$ & NT & 4 & NT/NT/NT \\
\hline $15 y$ & $M$ & NT & 4 & NT/PI.9/NT \\
\hline $16 y$ & $M$ & NT & 4 & NT/PI.3/NT \\
\hline $15 y$ & $M$ & NT & $2 a$ & $\mathrm{PI} .5 / \mathrm{PI} .2 / \mathrm{NT}$ \\
\hline $15 y$ & $M$ & $Y$ & NT & $\mathrm{PI} .5 / \mathrm{NT} / \mathrm{NT}$ \\
\hline $16 y$ & M & $C$ & $2 \mathrm{a}$ & $\mathrm{PI} .5 / \mathrm{PI} .2 / \mathrm{NT}$ \\
\hline $16 y$ & $M$ & C & $2 a$ & $\mathrm{PI} .5 / \mathrm{PI} .2 / \mathrm{NT}$ \\
\hline $16 y$ & $M$ & C & $2 a$ & PI.5/PI.2/NT \\
\hline $17 y$ & M & $C$ & $2 a$ & $\mathrm{PI} .5 / \mathrm{PI} .2 / \mathrm{NT}$ \\
\hline $17 y$ & $M$ & $C$ & $2 a$ & $\mathrm{PI} .5 / \mathrm{PI} .2 / \mathrm{NT}$ \\
\hline $15 y$ & $M$ & NT & $2 \mathrm{a}$ & $\mathrm{PI}$.5/PI.2/NT \\
\hline $15 y$ & $\mathrm{~F}$ & $Y$ & NT & PI.5/PI.I0/NT \\
\hline $16 y$ & $M$ & $Y$ & NT & PI.5/PI.I0/NT \\
\hline $16 y$ & M & $C$ & $2 a$ & $\mathrm{PI} .5 / \mathrm{PI} .2 / \mathrm{NT}$ \\
\hline $18 y$ & M & $\mathrm{Y}$ & NT & PI.5/PI.I0/NT \\
\hline $17 y$ & M & NT & 4 & NT/PI.I3/NT \\
\hline $17 y$ & M & $C$ & 4 & NT/NT/NT \\
\hline $18 y$ & $M$ & NT & $2 a$ & PI.5/PI.I0/NT \\
\hline $15 y$ & $M$ & $Y$ & NT & PI.5/PI.I0/NT \\
\hline $19 y$ & M & NT & NT & NT/NT/NT \\
\hline $12 y$ & M & NT & NT & NT/NT/NT \\
\hline $9 y$ & $M$ & $A$ & $?$ & $?$ \\
\hline $18 y$ & M & $Y$ & $?$ & $?$ \\
\hline $18 y$ & M & $Y$ & $?$ & $?$ \\
\hline $19 y$ & $M$ & WI35 & $?$ & $?$ \\
\hline $17 \mathrm{~m}$ & $M$ & B & $?$ & $?$ \\
\hline $12 \mathrm{~m}$ & $\mathrm{~F}$ & B & $?$ & $?$ \\
\hline $4 y$ & $M$ & $B$ & $?$ & $?$ \\
\hline $3 m$ & $\mathrm{~F}$ & B & $?$ & $?$ \\
\hline $8 \mathrm{~m}$ & $M$ & $x$ & $?$ & $?$ \\
\hline $14 \mathrm{~m}$ & M & $Y$ & $?$ & $?$ \\
\hline $\mathrm{IIm}$ & $\mathrm{F}$ & WI35 & $?$ & $?$ \\
\hline $15 \mathrm{~m}$ & $M$ & $\mathrm{Y}$ & $?$ & $?$ \\
\hline $18 \mathrm{~m}$ & M & $Y$ & $?$ & $?$ \\
\hline $5 y$ & $M$ & $Y$ & $?$ & $?$ \\
\hline
\end{tabular}

$M=$ masculine

$\mathrm{F}=$ female

$\mathrm{NT}=$ not typable

$y=$ year

$\mathrm{m}=$ month

?= not submitted to subtype

ET37 complex $=2 \mathrm{aPI} .5-\mathrm{PI} .2$ where colonization takes place on the surface cells of the mucosa and in the intraepithelial and sub-epithelial cells. Prior damage to the surface of the mucosa can be the first step to colonization. ${ }^{25}$ We also know that the highest rates of colonization may coincide with the appearance of outbreaks and during the endemic period of the infection the carrier could be as high as $10 \% ; 5$ thus, active awareness of this fact is always advisable. During the study period no outbreaks were reported in Mexico City or in the places where the samples were taken.

Of the serogroups that are prevalent in carriers as opposed to serogroups that produce invasive disease, half are non-capsulated strains, and consequently, they cannot be classified or grouped and they have greater colonizing facility, while the capsulated strains have greater capacity to invade and avoid the host's defense mechanisms. ${ }^{25}$ We found that the most frequently isolated serogroup was the $Y$ group (29.7\%), followed by the C serogroup (24.3\%). When a comparison was made with a study to characterize carrier genotypes in students at Emory University, it was found that within a group of 2730 students, $N$ meningitidis was cultivated in $7.7 \%$; the most prevalent clone was the ET-37complex and the second most prevalent was the Y ET $-508.27,28$ Of the few serotype data obtained (23 isolates) for serogroup $C$ isolates, they were phenotypically identical to the ET37 (2a, P1.5/P1.2) complex, that corresponds to 43.4 per cent.

It is known that the distribution of serogroups has seasonal geographical variations in both carriers and invasive disease. For example, in the United States from 1988 to 1991 most cases of invasive disease was caused by $B$ and $C$ serogroups and the $Y$ group only represented $2 \%$ of the cases, while from 1996 to 2001 serogroup Y caused $39 \%$ of cases, followed by serogroup C (31\%) and serogroup B $(23 \%){ }^{26}$

The data derived from our studies agree with the findings reported in the United States both in types of serogroups isolated and in age groups affected. We believe that from the epidemiological point of view there are similarities in the carrier colonization data in our country and in the United States. However, the difference as to incidence and prevalence of the invasive disease is highly evident. This may be due to under-reporting of meningococcal disease and/or the fact that the population in Mexico has transitory immunological protection -particularly what has been called innate newborn immunity-related to genetic factors that provide time-limited protection. This gives the individual the chance to defend himself during stages of greater risk of serious invasive disease, which are the neonatal stage and the first three months of life, and thus to be 
able to be colonized and develop immunity against virulent strains.

These response differences between various age groups must be demonstrated by carrying out studies to this regard in order to explain these differences.

In connection with preventive measures such as both polysaccharide and conjugated vaccinations, without knowing the real burden of the disease, we do not, at the moment, consider this as a universal recommendation. On the other hand, it could be recommended for groups at risk and also for implementing a national study of carriers and of invasive disease burden in order to discover the prevalence of the predominant serogroups and the effect of vaccinations currently available in our country and around the world.

Data is limited since this is a non-probabilistic pilot study and, consequently, more information is required about subjects, carriers and disease burden, particularly at the national level.

Considering that meningococcal disease has a variety of clinical manifestations affecting certain groups and that it could be a conditioning factor for serious and even fatal effects, we need to take very seriously the role in prevention of the new conjugated vaccines which protect the most vulnerable groups. In addition, we need to take into account the fact that if we knew more about this disease from the epidemiological point of view, specific recommendations could be made to prevent it.

\section{References}

I. Soult Rubio JA, Muñoz Sáez M. Invasive meningococcal disease.An Pediatr (Barc). 2005;62(4):297-303.

2.World Health Organization. Control of Epidemics Meningococcal Disease:Who practical Guidelines, 2nd ed. Geneva:WHO, 1998. [Available at: http:/www.who.int/emc]

3. Cartwright KA, Stuart JM, Jones DM, Noah ND. The Stonehouse survey: nasopharyngeal carriage of meningococci and Neisseria lactamica. Epidemiol Infect 1987;99(3):59|-60I.

4. Caugant DA, Høiby EA, Magnus P, Scheel O, Hoel T, Bjune G, et al. Asymptomatic carriage of Neisseria meningitidis in a randomly sampled population.J Clin Microbiol 1994;32(2):323-330.

5.Tikhomirov E, Santamaria M, Esteves K. Meningococcal disease: public health burden and control.World Health Stat Q 1997;50(3-4): I70-I77. 6. Rosenstein NE, Perkins BA, Stephens DS, Popovic T, Hughes JM. Meningococcal disease. N Engl J Med 200 I;344(I8): I378-I388.

7. Brooks RB,Woods CW. Neisseria meningitidis outbreaks in the United States 1994-2002. In:Abstracts of the 4Ist Annual Meeting of the Infectious Diseases Society of America, San Diego, California. October 9-II, 2004:8I-2

8. Jackson LA, Schuchat A, Reeves MW,Wenger JD. Serogroup C meningococcal outbreaks in the United States. An emerging threat. JAMA 1995; 273(5):383-389.
9. Faber J, Schuessler T, Finn A, Murdoch C, Zenz W, Habermehl P, et al. Agedependent association of human mannose-binding lectin mutations with susceptibility to invasive meningococcal disease in childhood. Pediatr Infect Dis J 2007;26(3):243-246.

10. Einhorn MS, Weinberg GA,Anderson EL, Granoff PD, Granoff DM. Immunogenicity in infants of Haemophilus influenzae type $B$ polysaccharide in a conjugate vaccine with Neisseria meningitidis outermembrane protein. Lancet 1986;2(8502):299-302.

II. Exley RM, Goodwin L, Mowe E, Shaw J, Smith H, Read RC, et al. Neisseria meningitidis lactate permease is required for nasopharyngeal colonization. Infect Immun 2005;73(9):5762-5766.

I2. Siamak PY, Kriz P, Tzanakaki G, Kremastinou J, Kalmusova J, Musilek $M$, et al. Distribution of Serogroups and Genotypes among DiseaseAssociated and Carried Isolates of Neisseria meningitidis from the Czech Republic, Greece, and Norway. J Clin Microbiol 2004;42(I I):5I 46-5I 53. 13. Frasch CE, Zollinger WD, Poolman JT. Serotype antigens of Neisseria meningitidis and a proposed scheme for designation of serotypes. Rev Infect Dis $1985 ; 7(4): 504-510$.

14. Kirsch EA, Barton RP, Kitchen L, Giroir BP. Pathophysiology, treatment and outcome of meningococcemia: a review and recent experience. Pediatr Infect Dis J 1996; 15(I I):967-978.

15. Pollard AJ, Levin M.Vaccines for prevention of meningococcal disease. Pediatr Infect Dis J 2000; 19(4):333-344.

16. Balmer P, Miller E. Meningococcal disease: how to prevent and how to manage. Curr Opin Infect Dis 2002;15(3):275-28I.

17. Bilukha O, Rosenstein N. National Center for Infectious Diseases, Centers for Disease Control and Prevention (CDC). Prevention and control of meningococcal disease. Recommendations of the Advisory Committee on Immunization Practices (ACIP). MMWR Recomm Rep 2005 May 27;54(RR-7):I-2I.

18. Van Deuren M, Brandtzaeg P, van der Meer JW. Update on meningococcal disease with emphasis on pathogenesis and clinical management. Clin Microbiol Rev 2000; I3(I): I44-I66.

19. Jolley KA, Kalmusova J, Feil EJ, Gupta S, Musilek M, Kriz P, et al. Carried meningococci in the Czech Republic: a diverse recombining population.J Clin Microbiol 2000;38(I2):4492-4498.

20. Sparling PF.A plethora of host factors that determine the outcome of meningococcal infection. Am J Med 2002; I I2(I):72-74

2I. Sistema Nacional de Vigilancia Epidemiologica.Anuarios de Morbilidad de la Direccion General de Epidemiologia 2000-2004 (Morbility yearbook from the Epidemiology General Management 2000- 2004). Available at: http/www.dgepi.org.mx

22. Janda WM, Knapp JS. Neisseriaceae. In: Manual of Clinical Microbiology Ed. Murray P, Baro E, Jorgensen J, Pfaller M y Yolken R. 8th Ed.Washington DC:American Society for Microbiology, 2003:585.

23.Popovic T,Ajello G, Facklam R. Laboratory Methods for the diagnosis of meningitis caused by Neisseria menigitidis, Streptococcus penumoniae and Haemophilus influenzae. Manual. Geneva: WHO, 1998.

24.Wedge E, Hoiby E, Rosenqvist E, Froholm L. Serotyping and subtyping of Neisseria meningitidis isolates by co-agglutination, dot-blotting and ELISA.J Med Microbiol 1990;31:195-20I

25.Ala'Aldeen DA, Neal KR, Ait-Tahar K, Nguyen-Van-Tam JS, English $A$, Falla TJ, et al. Dynamics of meningococcal long-term carriage among university students and their implications for mass vaccination.J Clin Microbiol 2000 ;38(6):23 I I-23I6.

26. Active Bacterial Core Surveillance (ABCs) (1997-2002)

Meningococcal surveillance reports.Available at: www.cdc.gov.ncidod/ abcs/ [consulted July I5, 2004]

27. Yazdankhah SP, Caugant DA. Neisseria meningitidis: an overview of the carriage state. J Med Microbiol 2004;53(Pt 9):821-832.

28. Kellerman SE, McCombs K, Ray M, Baughman W, Reeves MW, Popovic T, et al. Georgia Emerging Infections Program. Genotype-specific carriage of Neisseria meningitidis in Georgia counties with hyper- and hyposporadic rates of meningococcal disease. J Infect Dis 2002; I86(I): $40-48$. 